Piśmiennictwo zakonne $w$ dobie staropolskiej, red. Magdalena Kuran, Katarzyna KaczorScheitler i Michał Kuran, przy współpracy Dawida Szymczaka, Łódź 2013.

Dorota SZagun ${ }^{1}$

Uniwersytet Zielonogórski

\title{
Językowy wyraz pobożności w szesnastowiecznej regule Zakonu Świętej Klary. Cnota ubóstwa jako główny element aktu normatywnego
}

Każdy zakon organizuje życie wspólnoty wokół najważniejszych cnót zakonnych, reguła zakonu, jako akt normatywny danej wspólnoty, z założenia także powinna być ukształtowana na ich kanwie, a w konsekwencji przez pryzmat cnót porządkować szczegółowo podstawowe sfery życia zakonnego. W zależności od danej konkretnej wspólnoty religijnej, monastycznej, a zarazem komunikacyjnej nieco inaczej rysuje się w tym zakresie językowy obraz jej doświadczeń. Wśród zakonów żebraczych, w tym franciszkanów i klarysek, podstawą są zasadnicze cnoty ewangeliczne; w Zakonie Braci Mniejszych są to: ubóstwo, posłuszeństwo i czystość, a w Zakonie Świętej Klary: ubóstwo, posłuszeństwo, czystość i życie w zamknięciu (klauzura). W poszczególnych wspólnotach zakonnych repertuar cnót może podlegać modyfikacjom, a każdy z tych przymiotów może uzyskiwać inne natężenie i konkretną realizację, wyrażaną także za pomocą określonych środków językowych w konstytucjach i przepisach dotyczących życia zakonnego.

W niniejszym artykule oglądowi poddajemy językowy wyraz pobożności kształtowany na podstawie pierwszej z wymienionych cnót w regule świętej Klary, która z różnych względów, jak przedstawimy, wydaje się dla tego zgromadzenia cnotą kardynalną. Tekst zatem dotyka tylko jednej z czterech zasad życia zakonnego, choć pozostałe pryncypia życia mniszek splatają się z sobą w opi-

\footnotetext{
${ }^{1}$ Dorota Szagun — doktor, adiunkt w Zakładzie Historii i Pragmatyki Języka Polskiego w Instytucie Filologii Polskiej Uniwersytetu Zielonogórskiego. Przedmiotem jej zainteresowań naukowo-badawczych są dzieje używania języka polskiego, ze szczególnym uwzględnieniem aspektów komunikacji wspólnoty narodowej XVII/XVIII i XIX wieku oraz zagadnienia dotyczące stylu artystycznego. Autorka książek: Uksztattowanie leksykalno-stylistyczne poezji religijnej Kornela Ujejskiego (Zielona Góra 2006); Jedna pieśn — dwa dzieła. Szkice o dwóch wersjach Pieśni nad pieśniami w romantyzmie (Zielona Góra 2011) oraz artykułów o różnorodnej tematyce językoznawczej, np.: Biblijny genetivus partitivus czy forma superlatywu w poezji Cypriana Norwida?, „Język Polski” 2002, z. 1; Drobiazg językowy, czyli stowo o handoucie, „Poradnik Językowy” 2007, z. 10; Kilka cech języka osobniczego K. Ujejskiego, „Rozprawy Komisji Językowej ŁTN” 2008, t. 53; Konotacje aksjologiczne liczby i ilości na podstawie wybranych zwiazków wyrazowych, [w:] Ilość - wielkość - wartość, red. E. Umińska-Tytoń, Łódź 2010; Kategoria czasu w Biblii Tysiaclecia na tle Biblii Jakuba Wujka. Próba porównania, [w:] Zielonogórskie Seminaria Jezykoznawcze, red. St. Borawski, M. Hawrysz, Zielona Góra 2011.
} 
sie zasad i przejawów pobożności wpisanych w regułę klasztorną. W niektórych fragmentach tekstu nie sposób oddzielić więc od siebie poszczególnych cnót, działanie takie byłoby zresztą ze szkodą dla oglądu podejmowanych zagadnień.

Podstawą materiałową opracowania jest polski późnośredniowieczny tekst reguły zakonu klarysek, z chronologią ustaloną na początek XVI lub przełom XV/XVI wieku, pochodzący z rękopisu Biblioteki Zakładu Narodowego im. Ossolińskich, oznaczonego w Inwentarzu rękopisów... ${ }^{2}$ sygnaturą 1874/I i incipitem: Poczyna sya Regula Polska panney swyenthei Clarj. Reguła ta trzykrotnie doczekała się wydania przez Stanisława Borawskiego. Wydanie pierwsze ukazało się w 1995 roku w postaci transliteracji grafemicznej zabytku ${ }^{3}$, kolejne z roku $2002 \mathrm{w}$ formie transliteracji uproszczonej, opatrzonej przez Autora obszernym wprowadzeniem filologicznym ${ }^{4}$ a wydanie trzecie z 2007 roku w postaci transliteracji uwzględniającej zmiany i poprawki edycji z 1995 roku, a także podobiznę zabytku i konkordancję materiału leksykalno-grafemicznego ${ }^{5}$. Zabytek jest rękopisem polskim, jest też prawdopodobnie kolejnym, nie pierwszym, odpisem jakiegoś wcześniejszego dokumentu ${ }^{6}$. Jest bowiem bardzo mało prawdopodobne, że pierwsza wersja dokumentu, tłumaczona albo bezpośrednio z łaciny, albo z czeskiego, była spisywana przez wielu skrybów"', a jak w swoich badaniach sugeruje St. Borawski, w rękopisie wyraźnie widać kilka „rąk pisarskich”8. Rękopis składa się z 24 pergaminowych kart o formacie quarto i paginacją zapisaną cyframi arabskimi na stronach recto w prawym górnym rogu. Pod względem zawartości treściowej jest to reguła zakonna klarysek nadana konwentom przez papieża Urbana IV w 1263 roku. Tekst składa się z 26 rozdziałów funkcjonalnie stanowiących zbiór szczegółowych przepisów i norm życia mniszek, między innymi: „Które powiada aby Siostry w Klasztorze zawżdy w zamknieniu mięszkały” (Reguła, 4r, 5), „O przyjmowaniu Siostr i o ich Profesjej” (Reguta, 5r, 9) czy „O pannie Ksieni i o ji urządzie” (Reguła, 18v, 23). Większość partii tekstu odnosi się do bardzo praktycznej strony organizacji życia zakonnego, choć nie brak w niej, nielicznych co prawda, odniesień do sfery duchowej, zwłaszcza w zakresie zasad praktykowania poszczególnych cnót i ascezy.

Jak już wspomnieliśmy, cnota ubóstwa wydaje się szczególnie ważna w odniesieniu do reguły zakonnej świętej Klary. Z punktu widzenia języka polskiego, już przez sam

\footnotetext{
${ }^{2}$ Inwentarz rękopisów Biblioteki Zakładu Narodowego im. Ossolińskich we Wroctawiu opracowany zbiorowo pod redakcja dr Jadwigi Turskiej, bibliotekarki Zakładu. T. I: Rękopisy 1-7325, Wrocław 1948, s. 49.

${ }^{3}$ St. Borawski, Rękopis ZNIO, sygn. 1874/I: Reguta zakonu świętej Klary. I. Transliteracja zabytku, „Rozprawy Komisji Językowej Wrocławskiego Towarzystwa Naukowego", t. 21: 1995, s. 89-121.

${ }^{4}$ Tenże, Późnośredniowieczna 'Reguła zakonu panny św. Klary', [w:] Zielonogórskie seminaria polonistyczne 2001, red. St. Borawski i J. Brzeziński, Uniwersytet Zielonogórski 2002, s. 15-73.

${ }^{5}$ Tenże, Reguła zakonu świętej Klary. Wyrazy graficzne z lokalizacjami wraz z podobizną zabytku i transliteracją, Zielona Góra 2007. Dalej opatrywane skrótem: Reguła (karta i wers).

${ }^{6}$ Zob. M. Hawrysz, Grafia XVI-wiecznej reguly klarysek. Rekonesans badawczy, [w:] Dokument pisany $w$ badaniach historyka jezyka polskiego. Z badań nad grafia i fonetyka historycznej polszczyzny, red. M. Kuźmicki i M. Osiewicz, Zielona Góra-Poznań 2010, s. 224-225, 233.

${ }^{7}$ Tamże, s. 226-227.

${ }^{8}$ Zob. St. Borawski, Reguła zakonu świętej Klary....
} 
źródłosłów nazwy, cnota ta wydaje się wystarczająco istotna i interesująca, by zainspirować do przeprowadzenia eksploracji i analiz językowych. Jak mało która nazwa cnoty zakonnej, ubóstwo posiada bowiem genetyczny, etymologiczny związek z rdzeniem „ "bog-” (w prasłowiańszczyźnie 'bogactwo, szczęście, pomyślność, dolạ), czyli tym samym, od którego pochodzi w polszczyźnie nazwa „Bóg”. Wymiar sakralny ubóstwa wydaje się w języku sankcjonować także potoczne, o charakterze paronomazji zestawienie „ubogi” — „u Boga”. Oddaje to staropolskie przysłowie zbudowane na podobieństwie leksykalnym: „Ubogiemu Bóg nie ubogi” ${ }^{10}$. „Ubóstwo” jest wyrazem pochodnym od podstawy „ubogi”, która w polszczyźnie historycznej występowała zarówno w funkcji przymiotnika, jak i w użyciu rzeczownikowym 'człowiek ubogi'. Wyraz utworzony został za pomocą nieproduktywnego dziś formantu u- (oznaczającego 'brak, ubytek'), historycznie oznaczał 'nie mający Boga, tj. dostatku, szczęścia'11.

Ubóstwo - pauperitas, jest szczególną pod wieloma względami zasadą życia w wielu regułach klasztornych tzw. zakonów żebraczych, zwanych także mendykanckimi. W szczególny sposób związana jest więc z określonymi formami życia zakonnego, wyrosłymi z poszukiwania jeszcze głębszej ascezy, mającej wspomóc życie duchowe. Jednym z takich zgromadzeń był powołany w 1211 roku, zgodnie z regułą II zakonu świętego Franciszka, Zakon świętej Klary (Ordo Santae Clarae - OSC), nazywany także Zakonem Klarysek. Nowe zgromadzenie zakonne

od miejsca założenia klasztoru nazwano damianitkami. Św. Klara zwykła też używać określenia Panie lub Panny Ubogie, które funkcjonuje jeszcze w późniejszej bulli Innocentego IV. Nazwy te następnie stopniowo ustępowały miejsca określeniu Siostry Ubogie ${ }^{12}$,

a także Panny Bose. Nazwy zgromadzenia wyraźnie podkreślają szczególny jego charyzmat i stają się elementem wyróżniającym spośród całej rzeszy wspólnot zakonnych doby staropolskiej.

Od samego początku spośród cnót zakonnych właśnie ubóstwo, a w zasadzie sposób jego praktykowania, stanowiło wyróżnik wspólnoty franciszkańskiej i klariańskiej, ale także największą kontrowersję, jak na owe czasy, przyczyniając się do różnorakich interpretacji reguły klasztornej, a w konsekwencji nawet do podziałów wewnętrznych. W ten sposób wyodrębniły się poszczególne gałęzie zakonu franciszkańskiego: obserwanci, bracia konwentualni, kapucyni. Także w Zakonie Panien Ubogich liczne zmiany w regule zakonnej przeprowadzane były właśnie pod kątem łagodzenia lub

\footnotetext{
${ }^{9}$ Jest to etymologia ustalona przez takich badaczy, jak A. Brückner, F. Sławski, a także Z. Klemensiewicz, St. Urbańczyk; według A. Bańkowskiego należałoby jednak mówić o dwóch znaczeniach i dwóch rdzeniach *bog-, obok 'majątek', także 'budzący lęk', co wyjaśniałoby pochodzenie słowa bóg/Bóg; por. A. Bańkowski, Stownik etymologiczny języka polskiego, Warszawa 2000, t. 1, s. 65.

${ }^{10}$ Zob. B. S. Linde, Stownik języka polskiego, Lwów 1807, t. 1, s. 81, (przykład pochodzi z XVII wieku).

${ }^{11}$ Por. K. Długosz-Kurczabowa, St. Dubisz, Gramatyka historyczna jezyka polskiego, Warszawa 2003, s. 344 .

${ }^{12}$ A. Sutowicz, Fundacja klasztoru klarysek wrocławskich na tle fundacji innych placówek żeńskiego zakonu franciszkańskiego na ziemiach polskich, ,Perspectiva. Legnickie Studia Teologiczno-Historyczne” 2006, nr 2 (9), s. 122.
} 
zaostrzania zasad życia bez własności, a zatem szczegółowego rozumienia zasad zakonnego życia w ubóstwie.

Kardynał Hugolin wyznaczony do opieki nad nowymi wspólnotami z Asyżu (późniejszy Grzegorz IX) sporządził dla Klary zbiór praw, ale oparł je na regule św. Benedykta. Była to Reguła z 1219 roku, potwierdzona również w roku 1228, zwana „Konstytucje Hugoliańskie”). Klara nie była z tej reguły zadowolona, ponieważ nie dawała ona kształtu charyzmatowi, którym żyły damianitki, charyzmatowi „ubóstwa dla Chrystusa i z Nim”. Dlatego starała się, aby opieka duchowa zawsze była zapewniana przez braci Franciszka, a ponadto uprosiła papieża Innocentego III, a następnie Grzegorza IX i Innocentego IV o przyznanie jej szczególnego przywileju dołączanego do reguły. Jest to „Przywilej ubóstwa” dający siostrom prawo do nieposiadania majątku klasztornego ${ }^{13}$.

Ubóstwo stało się więc dla klarysek szczególnym i „,wyproszonym” (św. Klara broniła charyzmatu ubóstwa przez 27 lat, walcząc o osobny przywilej papieski) u prawodawców charyzmatem zakonnym.

Pomysł ten był bezprecedensową nowością, stawiającą paradoksalnie żeńską gałąź zakonu na równi $\mathrm{z}$ męską, $\mathrm{w}$ równym stopniu niezależności od finansowej woli fundatorów, a także podkreślającą niemniejszą funkcję społeczno-ewangelizacyjną sióstr mimo ich klauzurowego odcięcia od świata zewnętrznego ${ }^{14}$.

W rzeczywistości jednak większość klasztorów nie mogła przyjąć Reguły Klary, gdyż była ona zatwierdzona dla klasztoru w Asyżu i nie było papieskiej zgody na szersze jej praktykowanie. Ostatecznie w zakresie praktyki przyjmowania reguły

[...] w pozostałych zgromadzeniach obowiązywała bądź reguła kardynała Hugolina, bądź też Innocentego IV, który w 1247 roku zatwierdził formam vitae wprowadzającą do benedyktyńskiego stylu życia klasztorów klarysek elementy franciszkańskie, takie jak posługa franciszkanów, ich pomoc materialna i duchowa, przywilej ubóstwa, posłuszeństwo klarysek wobec Kościoła z posługą głoszenia Ewangelii. Ta różnorodność obowiązujących reguł wynikała z dużej autonomii poszczególnych klasztorów ${ }^{15}$.

Nie było więc jednej wspólnej reguły i różnie rozumiano istotę przywileju ubóstwa w poszczególnych wspólnotach zakonnych.

Próby uporządkowania życia klasztornego tak wielkiej rodziny zakonnej podjął się w 1263 roku papież Urban IV, który sporządził nową regułę, bardzo obszerną i szczegółową. Choć posiadała ona charakter franciszkański, również zezwalała na posiadanie własności materialnej oraz wyjmowała klaryski spod bezpośredniej jurysdykcji franciszkanów. Niektóre jednak klasztory, na czele ze wspólnotą św. Damiana, pozostały przy regule Klary zatwierdzonej w 1253 roku przez Innocentego IV ${ }^{16}$.

Reguła zakonu klarysek na ziemiach polskich, a zwłaszcza kluczowa kwestia ubóstwa, odbiegała znacznie od pierwotnej formy wypracowanej przez świętą Klarę. Zarówno hierarchia kościelna, jak i (a może nawet głównie) zakony męskie, którym Rzym powierzał opiekę nad klaryskami, wykazywały niechęć wobec demonstracyjne-

\footnotetext{
${ }^{13}$ Dostęp 05 sierpnia 2010, dostępny: <http://www.klaryski.pl/hist.htm\#03>.

${ }^{14}$ A. Sutowicz, dz. cyt., s. 123.

${ }^{15}$ Tamże, s. 123.

${ }^{16}$ Tamże, s. 124.
} 
go ubóstwa młodych zakonów ${ }^{17}$, ale zapewne obawiały się także, że połączenie przywileju ubóstwa z klauzurą uniemożliwi Pannom Ubogim pozyskanie niezbędnych do życia środków, zdając je tym samym na pomoc materialną zakonów męskich i na nie przerzucając obowiązki finansowe (tak stanowiła reguła Innocentego IV z $1247 \mathrm{roku}$ ). W rzeczywistości także same klaryski, pragnąc samostanowienia, mogły się obawiać takiej zależności. Na ziemiach polskich klasztory klarysek, oparte na regule zatwierdzonej przez Innocentego IV i bulli znoszącej nakaz najwyższego ubóstwa, uzyskiwały protekcję zamożnych fundatorek z dynastii Piastów, tak jak to było w przypadku Anny Czeskiej, żony Henryka II Pobożnego.

Faktem jest, iż w późniejszym klasztorze klarysek we Wrocławiu przebywały najznakomitsze przedstawicielki rodu Piastów nie tylko śląskich, lecz także wielkopolskich. Tu chowano po śmierci książęta i księżne piastowskie aż do XVIII wieku, traktując fundację Anny jako materialne, kulturalne i religijne dziedzictwo rodziny książęcej. O chęci zapewnienia bytu swoim potomkiniom świadczy przede wszystkim wielka dbałość fundatorki o stronę materialną klasztoru oraz od połowy XIV wieku wymóg wnoszenia przez każdą nowo przyjętą zakonnicę wysokiego posagu ${ }^{18}$.

Posag miał zabezpieczyć byt klasztoru, gdyż chętnych, by wstąpić w mury klasztorne zwykle było więcej, niż klasztor był zdolny wyżywić ${ }^{19}$.

W szybkim czasie klasztory klarysek stały się ośrodkami skupiającymi w swych murach potomkinie najwybitniejszych linii piastowskich, które sprawowały w nich najważniejsze funkcje zakonne. Dopiero w XIV wieku za specjalnym przyzwoleniem papieskim do klarysek zaczęły wstępować córki mieszczańskie ${ }^{20}$.

W rezultacie właśnie kwestia posiadania majątku klasztornego, a więc nakaz najwyższego ubóstwa został zmieniony na formę braku własności indywidualnej, przy zachowaniu jednakże własności wspólnej. Różne stanowiska w zakresie szczegółowego interpretowania kwestii własności przyczyniły się do zróżnicowania prawnego poszczególnych klarysek i współwystępowania aż czterech reguł: Grzegorza IX w typie benedyktyńskim, ze specjalną regulacją klasztoru macierzystego damianitek; Innocentego IV (likwidującej zasadę absolutnego ubóstwa); świętej Klary (w surowości wzorowana na regule dla braci mniejszych) oraz reguła błogosławionej Izabeli, zatwierdzona w 1259 roku przez papieża Aleksandra IV ${ }^{21}$. Sam fakt powstania omawianego przez nas tekstu reguły zakonu klarysek motywowany jest więc ostatecznym i jednoznacznym rozstrzygnięciem kwestii jednej, wspólnej reguły klarysek na ziemiach polskich, z wyraźnym stanowiskiem w zakresie realizowania przez wspólnotę zakonną cnoty ubóstwa. Uporządkowania stanu prawnego i ostatecznego rozstrzygnięcia kwestii przywileju ubóstwa podjął się papież Urban IV, przygotowując nową wersję reguły, której odpis w języku polskim poddajemy oglądowi. Jak więc widać, potrzeba upo-

\footnotetext{
${ }^{17}$ St. Borawski, Późnośredniowieczna Reguła polska..., s. 23.

${ }^{18}$ A. Sutowicz, dz. cyt., s. 130.

${ }^{19}$ Zob. M. Borkowska, Życie codzienne polskich klasztorów żeńskich w XVII-XVIII wieku, Warszawa 1996.

${ }^{20}$ Tamże, s. 126, zob. też I. Czachorowska, Książka w rękach klarysek ślaskich, „Sobótka” 1966, nr 3,

s. 411; taż, O nowe spojrzenie na ślaskie średniowieczne klasztory żenskie, [w:] Studia z dziejów kultury

$i$ ideologii, red. R. Heck, Wrocław 1968, s. 101.

${ }^{21}$ Zob. St. Borawski, Późnośredniowieczna Reguła polska..., s. 29; M. Hawrysz, dz. cyt., s. 224.
} 
rządkowania stanu prawnego, a domyślnie rozstrzygnięcie kwestii ubóstwa, staje się główną motywacją powstania aktu normatywnego, jakim jest Reguła polska zakonu Panny św. Klary:

tak od Grzegorza Papieża naszego przodka ktory sia zakonem opiekał waszym, jako od inszych Papieżow dane wam były rozmaite Reguły i obyczaje życia na ktore sia też przodkowie wasi wrocićsie byli obwiązali. A dla tego namilsze w miłym boże corki. było to u nas proszenie, abyśmy ten wasz Zakon pewnym imieniem nadarzeli, abyśmi też was od tych rozmaitych ustaw i też ślubow wypuszczonych miłosiernie rozgrzeszeli. abyśmi wam też pewnej obyczaj życia wydali, ktory by mogł ciasność a gryzienie somnienia waszego uspokoić (Reguła, 2r, 18-24).

Dokument ujednolicił także nazwę dla klasztorów, znosząc określenia wcześniejsze, w tym charakterystyczną nazwę Panny Ubogie:

Ale iż w tym Zakonie was i insze pannej w tym Zakonie bandące $\mathrm{z}$ dawnych czasow rozmaitymi przezwiskami Zwano \{jedni\} ${ }^{22}$ Sorores, drudzy Moniales, niekiedy ubogie za $\left\{\right.$ konnicz ${ }^{23}$ ki Zakonu świentego Damiana. A tak wam pod tymi i inszymi przezwiskami nadany byli przywileje, odpusty (Reguła, 2v, 12).

wprowadzając w formie obligatoryjnej, wręcz jako zarządzenie nowe miano:

od tychmiast przykazujemy i uchwalamy, aby Profeski i siostry wszystkie Zakonu tego byli Zwany Siostry albo Zakonniczki Zakonu pannej Świentei Klary (Reguła, 2v, 22-24; 3r, 1).

Charakter dyrektywny wypowiedzi podkreśla szereg czasownikowy „przykazujemy i chwalamy”. „Przykazować”, według Stownika polszczyzny XVI wieku, to 'przykazywać swą wolę do wykonania a. przestrzegania', 'wydawać rozkaz, nakaz, polecenie', a przede wszystkim 'ustanawiać prawo, uchwalać, rozporządzać ${ }^{24}$. Jeśli uzupełnimy te czasowniki zaimkiem przysłówkowym „od tychmiast” (pisanym w staropolszczyźnie częściej łącznie „odtychmiast”), według SXVI w., 'w odniesieniu do momentu mówienia, przekazywania tekstu: od teraz, od chwili obecnej”25, poświadczonym głównie w pismach o charakterze prawnym: statuty, artykuły kancelaryjne lub religijne, typu: Biblia Jakuba Wujka, żywoty, kazania; uzyskamy wrażenie szczególnie surowego $\mathrm{w}$ tonie i bardzo kategorycznego rozporządzenia papieskiego. W kontekście tak rozumianych regulacji prawnych, mających na celu anulowanie wcześniejszych ustaleń, nie dziwi stosunkowo rzadkie odwołanie w tekście reguły do zakonnego charyzmatu ubóstwa. Wyraz „ubogi” pojawia się w całym tekście reguły zaledwie jeden raz i to właśnie przy okazji zniesienia funkcjonującej na niektórych obszarach nazwy „Panny Ubogie”. „Ubóstwo” natomiast przywołane jest jedynie dwukrotnie, zarówno za pierwszym, jak i za drugim razem w kontekście ślubów zakonnych, wymienione zostało jako cnota podejmowana przez nowo przyjętą siostrę:

\footnotetext{
${ }^{22}$ Miejsce uszkodzone w rękopisie.

${ }^{23}$ Tamże.

${ }^{24}$ Stownik polszczyzny XVI wieku, red. F. Pepłowski, K. Wilczewska, L. Woronczakowa, t. 33, Warszawa 2009, s. 337-339 (dalej: SXVI w.).

${ }^{25}$ Tamże, red. M. R. Mayenowa, F. Pepłowski, t. 20, Wrocław-Warszawa-Kraków 1991, s. 511.
} 
przez wszystek czas żywota mego, żyć a chować posłuszeństwo święte, dobrowolne ubóstwo. i czystotę, a mieszkać zawżdy w zamknieniu, tak jako taż nasza Reguła obmawia świenta (Reguła, 6r, 10-12).

Zwraca tu uwagę zarówno kolejność repertuaru cnót, jak i określenia, którymi zostały opatrzone. Pierwszą jest cnota posłuszeństwa świętego, drugą cnota dobrowolnego ubóstwa, kolejnymi czystość i życie (zawsze) w zamknięciu. Określenie „dobrowolne” ma podkreślić wolicjonalny, nie przymuszony, nie nakazany i świadomy akt ślubowania ubóstwa ${ }^{26}$. Analogicznie pojawia się w Regule słowo „ubóstwo” w kontekście ślubów zakonnych także za drugim razem:

A kiedy już rok wynidzie proby, mają Ślubić Ksieni posłuszeństwo Święte. Przytym mają Śliubić trwałość na miejscu. A na wieki żyć bez własności, w dobrowolnem ubostwie i w czystości żyć aż do śmierci (Reguta, 17v, 3-7).

W tym fragmencie podkreślone zostało dobrowolne ubóstwo, ale tylko przez synonimiczne wyrażenie ,życie na wieki bez własności”. Zarówno w pierwszym, jak i w drugim fragmencie, jest to wyraźnie ubóstwo w wymiarze indywidualnym, nie zaś wspólnotowym. Ubóstwo zakonne klarysek rozumiane jest zatem dwojako, inaczej w zakresie własności wspólnej, majątku klasztornego, warunkującego stabilność, bezpieczeństwo i niezależność danej wspólnoty, oraz w wymiarze indywidualnym, odnoszonym do postawy konkretnych, pojedynczych sióstr. Chociaż święta Klara starała się przez całe swe zakonne życie wywalczyć i usankcjonować ubóstwo na obydwu tych płaszczyznach życia zakonnego, broniąc charyzmatu całkowitego ubóstwa tyczącego własności prywatnej i wspólnej, ewolucja aktów normatywnych zakonu klarysek wyraźnie zmierza do zindywidualizowania ubóstwa. Widać to zarówno w zakresie odejścia od nazwy, która wprost zakładała ubóstwo wspólnotowe (Panny czy Siostry Ubogie $^{27}$ ), jak i w wyraźnym unikaniu kwestii normatywnych dotyczących ubóstwa odnoszonego do całego zgromadzenia. Oczywiście Reguła powołuje się na przykład życia świętej Klary we wzgardzie dla bogactwa:

wzgardziwszy bogactwy i pracami i też lubościami tego świata obłudnego, umyślieła albo obrała sobie w Zakonie żyć (Reguła, 1v, 23; 2r, 1-3).

z drugiej jednak strony znajdujemy w niej wyraźne regulacje prawne w zakresie zarządzania właśnie majątkiem klasztornym. W rozdziale O Prokuratorze Klasztornym i o jego Urzendzie pojawia się na przykład kwestia kontrolowania i troski („opatrzenia” 'zabezpieczenia') o „imienie” (,imienie”, ,jimienie”, według Stownika staropolskiego ${ }^{28}$, 'mienie, majątek, posiadanie) i „dobro” klasztorne:

\footnotetext{
${ }^{26}$ Por. „dobrowolny” w Stowniku polszczyzny XVI wieku, red. M. R. Mayenowa, F. Pepłowski, t. 5, Wrocław-Warszawa-Kraków-Gdańsk 1971, s. 126.

${ }^{27}$ Związek nazwy z pierwotną, surową regułą św. Klary zatwierdzoną przez papieża Innocentego IV w 1253 roku, wyraźnie widać w powołanym w 1988 roku „pierwszym i jedynym w Polsce klasztorem klariańskim opartym na tej właśnie regule”, Zakonie Ubogich Sióstr w Kaliszu [online], dostęp 29 października 2010, dostępny <http://www.opoka.org.pl/biblioteka/D/DZ/klaryski-kalisz2008.html>.

28 Dostęp 29 października 2010, dostępny: <http://staropolska.pl/slownik/info.php?nr=0\&litera=I\&id $=604>$.
} 
Dla opatrzenia i przejrzenia imienia a dobra Klasztornego aby tak mogło być dobrze sprawowano, tudzież i dobrze a wiernie opatrzono. Chcemy aby jeden opiekun a sprawca ktoryby był człowiek roztropny, mądry, tudzież też i wierni waszych Klasztorach był postanowion (Reguła, 18r, 15).

Opiekun miał dbać i zabezpieczać majątek klasztorny, sam jednak bez zgody sióstr, a zwłaszcza przeoryszy — ksieni niczego nie mógł postanowić:

Przy tym aby nie śmiał taki opiekun z imienia Klasztornego nic ani przedawać, ani zafrymarczać, ani zastawiać abo ktoremkolwiek obyczajem od Klasztoru oddalać, ależby to pirwy biło za dozwoleniem Ksieni tudzież i Konwentu (Reguła, 18v, 7).

Sama przeorysza natomiast miała raz na kwartał zdawać sprawę ze stanu majątku klasztornego pozostałym siostrom. Bardzo poważnie, konkretnie i kompetentnie podchodzi się więc w regule do stanu finansów wspólnoty zakonnej, zakładając dbałość o dobytek klasztorny, którego nie wolno było bez zgody sióstr, ani sprzedawać, ani „frymarczyć" 'wymieniać, handlować', ani też zastawiać. Majątek stanowił o stabilności i pewności bytu klasztoru, a więc tylko w szczególnych sytuacjach, „gdy jaką potrzebność gwałtowna potrzebuje” można było go nadwyrężać czy zadłużać. Stan finansowy miała wszystkim siostrom skrupulatnie przedstawiać przeorysza, tłumacząc się gruntownie, dając „racją a liczbę”, czyli nie tylko kwoty, ale i dowody czy przyczyny („racja”, według słownika Lindego ${ }^{29}$, 'powód, dowód, przyczyna') poczynionych wydatków. W tym wszystkim pobrzmiewa więc nie duch ubóstwa, ale zwyczajna troska o byt materialny klasztoru.

Omawiana Reguta, jeśli odnosi się do ubóstwa, to najwyraźniej głównie (jeśli nie jedynie) do sfery ubóstwa indywidualnego, regulując szczegółowo wewnętrzne zasady życia wspólnoty.

Reguła zatem nadawała skupisku czy zgromadzeniu orientację w dążeniu ku Bogu i nacechowanie formą ascetyczną lub duchową, a przy okazji porządkowała zbiorowe życie pod względem organizacyjnym ${ }^{30}$

i tak należałoby rozumieć bardzo szczegółowe niekiedy zasady życia zakonnego, z których jedynie pośrednio dowiadujemy się o ewangelicznych podstawach życia zakonnego.

W zakresie tak widzianych norm i dyrektyw, każdorazowo zamiast cnoty ubóstwa pojawia się w repertuarze zasad życia zakonnego brak własności oraz staranny opis jego rozumienia: „Drugie, aby niczego nieśmiali mieć własnego” (Reguła, 3v-20, 4r-1).

W zdaniu tym pozornie wydaje się, że utrzymany zostaje główny rys duchowości pierwszych klarysek, ale faktycznie jest to tylko zdanie mylące, bowiem brak własności przez siostry ślubowany dotyczy tych właśnie mniszek, nie oznacza braku majętności klasztornych, ale jego wspólne użytkowanie. Rzeczy mają być więc dla zakonnic „pospolite a spolne”, obydwa leksemy odwołują się do wspólnego korzystania z dóbr, a nie do ich braku (według Stownika staropolskiego, „pospolity” to 'ogólny, powszechny i publiczny' ${ }^{31}$, według SL, 'wielom abo wszystkim służący, spólny' ${ }^{32}$ ).

${ }^{29}$ S. B. Linde, dz. cyt., t. 5, Lwów 1859, s. 16 (dalej: SL).

${ }^{30}$ St. Borawski, Późnośredniowieczna Reguła polska..., s. 22.

${ }^{31}$ Dostęp 29 października 2010, dostępny <http://staropolska.pl/slownik/?nr=255\&litera=P\&id=1751>.

${ }^{32}$ S. B. Linde, $d z$. cyt., Lwów 1859, t. 4, s. 32. 
Dbałością o brak osobistego przywiązania do rzeczy materialnych miała się w sposób szczególny odznaczać Ksieni: „,ktoraby we wszytkim pospolitość abo iżby własności, nie miłowali ale spolność we wszytkim chowała” (Reguła, 19 r, 8-9).

Poza brakiem własności i wspólnotą rzeczy, każda siostra miała mieć niewiele rzeczy użytku osobistego, ściśle określonych pod każdym względem przez regułę klasztorną. Ich cechą podstawową wydaje się być jednak, nie tyle radykalna skromność, co zdroworozsądkowy umiar.

Według tej zasady złotego środka suknie mogą być dwie lub trzy; te szaty zakonne „niemają być ani nazbyt długie, ani krotkie” (Reguła, 6v, 11), płaszcze „ani długie barzo, ani też krotkie" (Reguła, 7r, 16), poza tym poszczególne części ubioru mają być „niedworne, niepyszne, niedrogie”, a czepce z prostego płótna białego.

Każda siostra ma mieć także „osobliwe” 'osobne’ swoje łóżko, z workiem lub zagłówkiem wypełnionym plewami albo sianem lub z pierza (jeśli się Ksieni tak spodoba), kołdry z wełny. Obligatoryjny charakter tych postanowień potwierdzają liczne formuły odwoławcze do Reguty, jako prawa i normy, które nie podlegają zmianie i są dane do przestrzegania, stojąc na straży cnotliwego życia mniszego:

To też chcemy mieć aby żaden nie śmiał ty naszy ustawy, ty Reguły naszy nadania i potwierdzenia naszego, tudzież też i rozgrzeszenia naszego łamać, abo mu sie upornie sprzeciwiać (Reguła, 24v, 10-13).

Siostry, a zwłaszcza Ksieni, podlegają stałej ocenie przez siebie, inne siostry lub wizytatora. Weryfikowana jest ogólna zasada czy żyją dobrze, czyli „według Reguły Święty”. (Reguta, 22v, 1), „A jeśliżeby wianc ktora z was obaczyła, iż nie tak żywie jako Reguła uczy, za przeszłe grzechy a wystempy ma mieć skruche a żałość" (Reguła, 24v, 4-6).

Przy tych bardzo drobiazgowych zasadach dotyczących poszczególnych sfer życia zakonnego widoczny jest jednak pewien margines swobody i wyboru.

Reguła klarysek, choć bardzo szczegółowa w wielu sprawach, zapewne nie wystarczałaby do bezkolizyjnego praktykowania duchowej i cielesnej doskonałości, gdyby nie pozostawiała bardzo dużej liczby delegacji do jednostkowych rozstrzygnięć podejmowanych przez matkę przełożoną lub konwent in gremio ${ }^{33}$.

Sankcjonują to częste formuły typu: „według jako sia Ksieni podoba” (Reguła, 6v, 5), ,a to jeźliby sia podobało pannie Ksieni” (Reguła, 6v, 23-7r, 1), „według jako sia Ksieni uda a spodoba” (Reguła, 7v, 21-22), „Takież jeśliby sie pannie Ksieni widziało” (Reguta, 9v, 23-24) „jakoby sie pannie Ksieni widziało” (Reguta, 10v, 16), „i w insze ktorychby sie Ksieni widziało” (Reguła, 10v, 20-21). „Wszystkie konwenty Pań Ubogich cieszyły się jednak daleko posuniętą autonomią: przełożone decydowały o losach ich wspólnot, podlegając jedynie władzy biskupiej i papieskiej"34.

Ostateczny i decyzyjny głos matki przełożonej w wielu sprawach „rodzić może wątpliwości, czy prawodawca nie pozostawił jej zbyt wiele swobody, która w skrajnych przypadkach mogła prowadzić do samowoli” ${ }^{35}$, w rzeczywistości chyba jednak działa-

\footnotetext{
${ }^{33}$ St. Borawski, Późnośredniowieczna Reguła polska..., s. 23; Zob. też M. Hawrysz, dz. cyt., s. 225.

${ }^{34}$ A. Sutowicz, dz. cyt., s. 195.

${ }^{35}$ M. Hawrysz, dz. cyt., s. 225.
} 
nie tego rodzaju miało na celu poprawienie dyscypliny klasztornej. Bowiem w „początkach XVI w. wspólnota klarysek przechodziła wyraźny kryzys życia religijnego, odczuwalny jako brak utrzymania dyscypliny klasztornej i rozluźnienie klauzury"36. Ponadto Reguła wyraźnie wielokrotnie podkreśla, że rozstrzygające zdanie przeoryszy podyktowane jest głównie potrzebą. Ta przywoływana w regule „potrzeba” jest szczególną instancją, wydawałoby się duchową siłą warunkującą określony sposób życia wspólnoty klarysek. Potrzeba wewnętrzna powołała przecież poszczególne kandydatki do życia zakonnego: „tedy potrzeb jest, aby ta Zakonność i ten sposob życia w klastorze mieszkając zawżdy chowali” ${ }^{37}$ jednocześnie nierzadko przywoływana w regule „potrzebność” to po prostu ogół okoliczności, które każą na przykład po prostu dostosować długość habitu do wzrostu mniszki, ale też szczególne warunki pozwalające w wyjątkowych, jak można sądzić, sytuacjach modyfikować czy całkiem ignorować poszczególne zasady aktu normatywnego. Właśnie „potrzeba potrzebna” (charakterystyczna tautologia podkreślająca wymiar przymusu zewnętrznego) „gwałtowna, naskrętna” (według SL, „naskrętnie” — 'z pośpiechem”38) jest ostatnią instancją zdolną zmienić czy odwołać postanowienia reguły, albo dać przeoryszy powód do odstąpienia od jej nakazów. Potrzeba może dotyczyć tak złamania głównych zasad, co do obowiązku zakonnej klauzury, nakazu milczenia czy innych praktyk: rozmowy w miejscach do tego nie przeznaczonych, częstszego niż dozwolone puszczania krwi.

Stan posiadania rzeczy i praktykowania ascezy wyznaczają więc w zasadzie trzy najważniejsze instancje: reguła, przeorysza i ewentualnie potrzeba. Wagę tej pierwszej podkreśla sam prawodawca, nazywając ją „,regułą świętą”, nakazując klaryskom stałe wczytywanie się w jej nakazy i prowadzenie życia zgodnego z przekazywanymi przez regułę normami. Konieczność wyznacza uwikłanie człowieka w cielesność i stanowi, według licznych dokumentów, uzasadnienie dla własności klasztornych. Jak pisała święta Kinga księżna krakowska i fundatorka klasztoru sądeckiego:

postanawiamy założyć, a także zbudować dom wspólnego życia, czyli klasztor zakonnic reguły św. Klary w samym mieście Sączu [...] aby pozbywszy się działania wedle własnej woli, służyły w dzień i w nocy Panu w bojaźni i prowadziły życie w świętości i sprawiedliwości przed Chrystusem, wyrzekając się siebie i swojej własności, wybierając raczej surowe życie i wąską bramę, by osiągnąć podwoje życia wiecznego. Stąd $\mathrm{z}$ największą słusznością powinny być zaopatrzone w to, co należy do koniecznych warunków tego doczesnego życia [podkr. moje — D.S.], aby tym pobożniej, tym spokojniej, służyły Panu i same odnosiły korzyści przez zasługę życia, a innym dawały przykład przez modlitewną pomoc"39.

Cnota ubóstwa, chociaż genetycznie wydaje się głównym czynnikiem prowadzącym do powstania wspólnoty sióstr świętej Klary, a w konsekwencji obok posłuszeństwa, czystości i klauzury, jedną z najważniejszych cnót regulujących codzienne życie zakonne, w rzeczywistości, w zakresie polskiej reguły, będącej odpisem reguły Urbana

\footnotetext{
${ }^{36}$ A. Sutowicz, Życie religijne..., s. 217.

${ }^{37}$ Reguta, 3v, 17-19.

${ }^{38}$ S. B. Linde, $d z$. cyt., Lwów 1857, t. 3, s. 283.

${ }^{39}$ Żywot świętej Kingi księżnej krakowskiej. Vita sanctae Kyngae ducissae cracoviensis, tekst łaciński wraz z tłumaczeniem polskim i objaśnieniami przygotował do druku ks. B. Przybyszewski, Tarnów 1997, s. 60-61.
} 
IV z 18 października 1263 roku, nie odgrywa tak dużej roli, jak można się było tego spodziewać, w kształtowaniu aktu normatywnego. Decydujący wpływ miała raczej na zaistnienie samej potrzeby powstania omawianej konstytucji, jaką jest Reguła polska zakonu Panny św. Klary, niż na szczegółowe praktyki życia zakonnego przez nią wprowadzane. Pod tym względem Reguła obrastała stopniowo także w inne akty normatywne o charakterze uzupełniającym, jak to miało przykładowo miejsce w odniesieniu do klarysek wrocławskich. „Klaryski cieszyły się łaską poszczególnych papieży, którzy nie szczędzili im uwagi. Obok potwierdzeń nadania dóbr i rozstrzygania spraw związanych z mianowaniem prokuratorów i naborem do klasztoru panien spoza sfer książęcych, papieże interesowali się także powszednimi kłopotami konwentu, takimi jak na przykład krzywdy doznane od złodziei. W 1318 roku Jan XXII wydał bullę nakazującą ściganie ich także prawem świeckim. Dzięki przywilejowi Klemensa V klasztor był wyłączony z obowiązku oddawania kolekt z dóbr klasztornych, co zostało potwierdzone osobnym dokumentem z 6 II 1289 roku, a także przez papieża Bonifacego VIII w 1296 roku” $^{30}$. Elementy ewangelicznego ubóstwa przekute zostały w bardzo konkretne i szczegółowe dyrektywy unikania przez mniszki „jako wrzodu” przywiązania do dóbr doczesnych oraz przestrzegania przez poszczególne siostry ślubowanego braku własności osobistej i zachowywania wszystkiego jako dobra wspólnego. Dobro wspólne w postaci majątku klasztornego rozwijało się za to dobrze, uzupełniane przez kolejne patronki i fundatorki z rodu piastowskiego, które co znamienne, dożywając ostatnich lat życia w klasztorze, nie składały już ślubów. Potwierdzona licznymi dokumentami zasobność klarysek w dobra materialne, „kwitnący od XIV wieku handel ziemią i prebendami nie sprzyjał utrzymaniu ducha zakonnego. $Z$ pewnością więc nastąpiło znaczne rozluźnienie obowiązku klauzury” ${ }^{11}$, stojące $\mathrm{w}$ sprzeczności $\mathrm{z}$ wieloma postanowieniami Reguły. W rzeczywistości ta w szczegółach dość surowa reguła niejako zainicjowała taki stan rzeczy, odwołując wcześniejsze reguły i pisma papieskie, z przywilejem najwyższego ubóstwa na czele. $Z$ drugiej strony nie sposób nie przyznać szczególnej doniosłości temu dokumentowi, który stanowi ważną próbę ujednolicenia reguły licznych wspólnot klariańskich. Nie można też zapominać, że właśnie swoistość fundacyjna klasztorów św. Klary na ziemiach polskich dawała im szanse zaistnienia wobec oporu i lęku władz kościelnych i klasztorów męskich, mających sprawować opiekę nad żeńskimi gałęziami w zakresie ich samowystarczalności. Ponadto klasztory klarysek w Polsce były bardzo ważnymi ośrodkami kulturalnymi z bogatymi księgozbiorami, przykładano w nich wagę do starannego wykształcenia ${ }^{42}$, a niejednokrotnie propagowano nawet rozwój polskiej literatury ${ }^{43}$.

\footnotetext{
40 Tenże, Fundacja klasztoru klarysek..., s. 138.

${ }^{41}$ Tenże, Życie religijne..., s. 215.

${ }^{42}$ Zob. A. Sutowicz, Fundacja klasztoru klarysek..., s. 126.

${ }^{43}$ Zob. I. Czachorowska, dz. cyt., s. 411.
} 


\section{Linguistics Expression of Piety in XVI Century Polish Principle of St. Clare's Convent. Virtue of Poverty as the Main Element of the Normative Act}

\section{Summary}

This paper focuses on issues regarding history of use of the language, namely the way the language is used to express the piety, characterizing a communication group of the Polish St. Clare's Convent. The language material was extracted from XVI century Polish principle of St. Clare's Convent and, on the basis of the material, there was an attempt to reconstruct the meaning of poverty. As a result of lexical analysis of the vocabulary related to the virtue of poverty, which is a cardinal one for the Convent, a change in the meaning was proved and expressed in a normative act of the principle - in the direction of lack of personal property. Apart from non-language reasons of such a modification, the change is based on detailed instructions, which regulate the life in the Convent, and, therefore, the specificity of type of the text. 